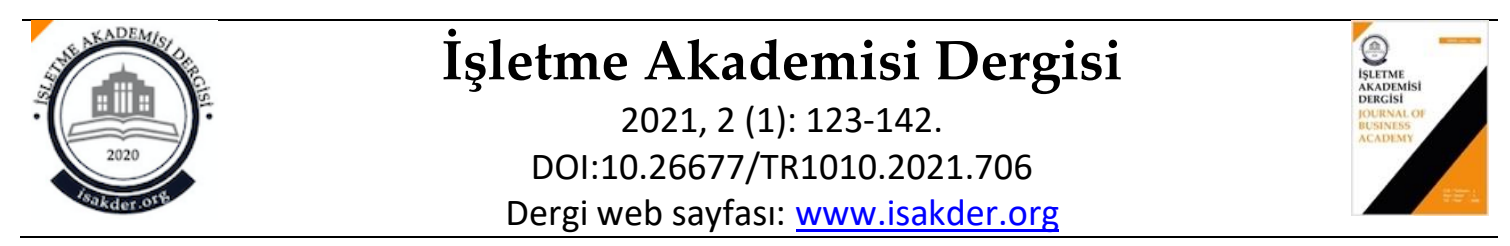

Araștırma Makalesi

\title{
Denetçi Adaylarının Denetimde Kanıt Kavramına Yaklaşımları Üzerine Bir Değerlendirme
}

\section{Dr. Ögr. Üyesi İlkay Ejder ERTURAN}

Düzce Üniversitesi, Çilimli MYO, Muhasebe ve Vergi Uygulamaları Bölümü ilkayerturan@duzce.edu.tr,www.orcid.org/0000-0003-2478-5634

\section{$\ddot{O} \mathbf{z}$}

Bu çalışmada, denetimde kanıt kavramı bağlamında son sınıfta öğrenim gören ve denetim dersi almış olan öğrencilerden, işletme yararına dahi olsa güvenilir kanıta dayanmayan belgeler kullanarak işlem yapmanın doğru olup olmadığı ile ilgili düşüncelerinin değerlendirilmesi amaçlanmıştır.

Araştırmanın, ana kütlesi, Düzce, Sakarya ve Bolu illerinde bulunan üniversitelerin fakülte ve yüksekokullarında denetim dersi almış son sınıf öğrencilerinden oluşmaktadır. 300 öğrenciye gönderilen anket çalışmasına yaklaşık olarak \% 60 oranın geri dönüş sağlanmıştır. Bu kapsamda 179 öğrenciye tarafından ankete geri, dönüş sağlanmıştır. Yöntem olarak "kolayda örnekleme yöntemi" kullanılmıştır. Öğrencilerinin konu hakkındaki düşüncelerini belirlemek amacıyla 5 soru sorulmuştur. Araştırma kapsamında oluşturulan 5 yargı 5'li likert tipi ölçekle ölçülmüş olup, yargılar en olumsuzdan en olumluya doğru sıralanmıştır.

Sonuç olarak, denetim yargısı oluşturmak için güvenilir kanıta ihtiyaç olduğu sonucuna ulaşılmıştır. Denetim yargısının güvenirliği denetim kanıtının kalitesi ve oluşturduğu makul güvence ile belirlenir. Denetçinin denetim kanıtına elektronik ortamda ulaşması için teknolojik bir altyapıya sahip olması gerekliliği ortaya çıkmıştır.

Anahtar Kelimeler: Denetim, Kanit, Elektronik Kanit, Denetçi

Makale Gönderme Tarihi: 17.02.2021

Makale Kabul Tarihi: 18.03.2021

\section{Önerilen Atıf:}

Erturan, İ. E. (2021). Denetçi Adaylarının Denetimde Kanıt Kavramına Yaklaşımları Üzerine Bir Değerlendirme, İşletme Akademisi Dergisi, 2(1): 123-142.

(C) 2021 İşletme Akademisi Dergisi. 


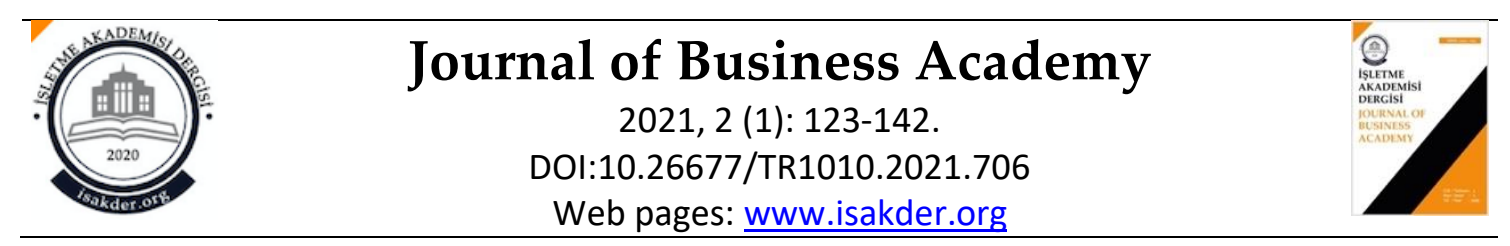

$\underline{\text { Research Article }}$

\title{
An Evaluation on the Approach of Auditing Candidates to The Evidence Concept in Audit
}

\author{
Asisstant Prof. Dr. İlkay Ejder ERTURAN \\ Düzce University, Çilimli Vocational School, Düzce, Turkey. \\ ilkayerturan@duzce.edu.tr, www.orcid.org/0000-0003-2478-5634
}

\begin{abstract}
In this study, it was aimed to evaluate the thoughts of students who studied in the last year and took an audit course in the context of the concept of evidence in audit, whether it is correct to make transactions using documents that are not based on reliable evidence, even for the benefit of the business.

The main body of the study consists of senior students who have taken audit lessons in faculties and schools of universities in Düzce, Sakarya and Bolu provinces. Approximately $60 \%$ of the survey was sent to 300 students. In this context, 179 students returned to the questionnaire. As a method, "convenience sampling method" was used. In order to determine the students' opinions on the subject, 5 questions were asked. The 5 judgments created within the scope of the research were measured with a 5-point Likert-type scale, and the judgments were ranked from the most negative to the most positive.

As a result, it has been concluded that reliable evidence is needed to form an audit judgment. The reliability of audit judgment is determined by the quality of audit evidence and the reasonable assurance it creates. It has emerged that the auditor must have a technological infrastructure in order to access audit evidence electronically.
\end{abstract}

Keywords: Auditing, Evidence, Electronic Evidence, Auditor

Received: 07.02.2021

Accepted: 18.03 .2021

\section{Önerilen Atıf:}

Erturan, İ. E. (2021). An Evaluation on the Approach of Auditing Candidates to The Evidence Concept in Audit, Journal of Business Academy, 2(1): 123-142.

(C) 2021 Journal of Business Academy. 


\section{GİRIŞ}

Bilginin güvenirliği ve kanıta dayalı olması nitelikli bilgi açısından büyük önem taşımaktadır. Zira günümüz teknolojileri sayesinde hemen hemen her tür bilgiye zaman ve mekandan bağımsız olarak ulaşabilmek oldukça kolay hale gelmiştir. Bu gelişmeler tüm alanlarda olduğu gibi denetim alanında da etkili olmuştur.

Günümüzde artık bilgi teknolojileri sayesinde muhasebe verileri dijital ortama taşınmış ve mesleki uygulamaların kanıta dayalı olması gerekliliği tartışılamaz olmuştur. Kanıta dayanan bilgi güvenilirdir. Denetimde kanıt, önceden belirlenmiş kriterlere uygun olarak muhasebeye konu olan her tür bilgi ve belge bütünüdür. Denetimde kanıt kavramı denetçiye denetim sürecinde ışık tutan ve denetim yargısını oluşturmakta yardımcı olan en önemli dayanaktır. Finansal tablolarda üretilen bilgilerin bilgi kullanıcıları açısından doğru ve güvenilir bilgi olduğunu onaylayan denetçi, bu onay işlemini geçerli, güvenilir ve zamanlı denetim kanıtlarına dayandırmalıdır. Finansal tablolar, denetlenen işletme yöneticilerinin savlarına dayanmakta olduğu için, bilgi kullanıcıları ile yöneticiler arasında çıkar çatışmasına neden olabilir. Bu çatışma denetçi üzerinde baskı oluşturabilir. Denetçinin yargısını oluşturmada güvenilir kanıtlar sunması ve baskılardan etkilenmemesi önem taşır. Bilgi kullanıcılarına doğru ve güvenilir bilgi sunmak ancak finansal tabloların doğruluğunu belgelemek ve güvenilir kanitlarla desteklemekle mümkün olabilir. Kanıt rasyonel temellere dayanmalı ve nesnel olmalıdır. Kanit toplama aşamasında denetçi öznel bir yaklaşım sergilememelidir. Denetim kanıtı basılı geleneksel olabileceği gibi elektronik belge niteliğinde de olabilir. Özellikle günümüzde geleneksel kanıtlardan daha fazla elektronik ortamda bulunan belge ürettirilmektedir. Bu nedenle denetçi bu belgeleri incelerken daha dikkatli olmalıdır.

\section{DENETIMDE KANIT KAVRAMI VE ELEKRONIK KANITLAR}

Denetimde kanıtı, işletmenin finansal tablolarının Genel Kabul Görmüş Muhasebe Standartlarına uygun hazırlanıp hazırlanmadığını gösterir. Denetçinin denetim yargısı oluşturmasına yardımcı olur. Günümüzde denetim kanıtları geleneksel yöntem olan kâğıt kalemle kaydedilmekten uzaklaşmış ve elektronik ortama taşınmıştır. Bu nedenle bu süreçte denetlenecek veriler geleneksel yöntemlerden uzaklaşmaya başlamış ve elektronik kanıtlar haline dönüşmüştür. Esas itibariyle muhasebe, kanıta dayalı rasyonel bir bilim olma özelliği taşımaktadır. Bu yönüyle belgeli, kanıta dayalı bilgi denetlenebilir ve bilgi kullanıcılarına güvenle sunulabilecek bilgi niteliğindedir.

\section{1. Denetim Kanitları}

Denetim kanıtı, denetçinin yargısına dayanak oluşturacak olan kriterlere uygunluğunu doğrulayan her türlü bilgi, belge ve kayıtlardır (Erdoğan, 2006). Uluslararası Denetim Standartları'na göre; denetçinin, denetim ile ilgili yargı oluşturabilmek için yeterli sayıda, uygun ve güvenilir denetim kanıtı toplaması gerekmektedir. Kanıt toplama işi denetim sürecinin her aşamasında devam eder. Çünkü denetçi, denetlenen işletme ile ilgili kabul edilebilir bir görüş bildirmeden önce yeterli sayıda kanıt topladığından emin olmalıdır.

Denetim kanıtı 2015 yılında Yoon tarafından; “işletmenin mali tablolarının genel kabul görmüş muhasebe ilkelerine uygun olarak hazırlanıp hazırlanmadı̆̆ı̆na karar verirken, denetçi tarafından toplanan ve değerlendirilen tüm bilgi kümesidir" ş̧eklinde tanımlamıştır" (Yoon, 2015: 431). Bir başka tanımda, denetimde kanıt kavramı; finansal tabloların düzenlenmesinden, denetçinin denetim raporunda yer alan görüşünün oluşmasına dek uzanan süreçte, denetime ilişkin bir dizi kavramın sistematik ilişkisi içinde yer almasıdır (Erdoğan, 2006: 54) şeklindedir. Denetimin önemli adımlarından biri de yeterli kanıtlara ulaşılmasıdır. 
Aktif bir denetimin için kanıtın nicel yeterliliği kadar kaliteli ve denetlenen konuya uygunluğu da önemlidir (Çetinkaya, 2017: 109). Kanıt denetçinin bağımsız yargısı için önem taşımaktadır. Bağımsız denetim standardı (BDS) 500'e göre denetim kanıtı:

"Denetçinin, görüşüne dayanak oluşturan sonuçlara ulaşırken kullandığı bilgilerdir. Denetim kanıtları, finansal tablolara dayanak (temel) oluşturan muhasebe kayıtlarındaki bilgiler ile diğer kaynaklardan elde edilen bilgileri içerir" şeklinde tanımlamıştır (https://www.kgk.gov.tr/Portalv2Uploads/files/Duyurular/v2/BDS/BDS_500_kurumsitesi.pdf).

Denetçinin amacı, denetim yargısına dayanak oluşturması beklenen kabul edilebilir nicel ve nitel açıdan yeterli kanıtları toplayabilecek bir yol haritası oluşturmaktır. Çünkü kanıtların güvenirliği denetçinin denetim sonucu oluşturacağı yargının nesnel olmasını sağlayacaktır. (Hatherly, 1980: 3). Denetim kanitında; en önemli zorluk, denetlenecek olan evrende örneklem büyüklügünün tespit edilmesidir. Denetçinin denetim yargısına ulaşmak, makul güvence elde etmek için denetime temel oluşturan bilgilerin ne kadarını doğrulayacağına karar vermesi gerekmektedir. Kanıtın amacı; bilgi kullanıcıları tarafından kabul edilebilir bir güvence oluşturmaktır. Kabul edilebilir güvence (makul güvence) ise, finansal tabloların içerik ve rakamsal bakımından önemli bir yanlışlık olmadığı konusunda yeterli sayıda ve amaca uygun bağımsız denetim kanıtının toplandığını göstermektedir. Denetimde kanıtın kalitesi, elde edilen kanıtın amaca uygun nitelikte, güvenilir ve denetçinin yargısı paralelinde oluşması demektir. (Çetinkaya, 2017:116). Denetim kanıtını inceleyen denetçi elde ettiği kanıtın mutlak bir doğruyu yansıtmayacağını, bu kanıtları oluşturan mali tabloların ve her çeşit finansal verilerin yönetimin savları olduğunu göz ardı etmemelidir. Denetçi için muhasebeye konu olan her türlü bilgi ve belge kanıt niteliğindedir. Denetçinin muhasebe verilerinden elde ettiği kanıtlara örnek olarak; bütün muhasebe verilerini gösterebiliriz. Bu muhasebe verilerini denetçi, destekleyici kanıtlarla (analiz raporları, toplantı tutanakları, doğrulamalar, soruşturma, gözden geçirme, fiziki inceleme gibi) doğrular (Cömert, Uzay, Kardeş, \& Uyar, 2013: 307). Kanıtın yeterliliği ve uygunluğu önemlidir. Yeterlilik kanıtın nicel olarak değerlendirilmesi iken uygunluk ise kanıtın nitel olarak değerlendirilmesidir. Denetim kanıtının denetim amacına uygunluğu ve yeterliliği denetçinin profesyonel yargısına bağlıdır (Erdoğan, 2006: 55). Bu nedenle denetim kanıtı sıkı kuralları olan yasal kanıtlardan farklılık göstermektedir.

Kanıt, güvenilir bilgi içermelidir. Güvenilir bilgi; toplanan yeterli kanıt miktarı ve kanıtın güvenilirliğiyle sağlanır. Toplanan denetim kanıtların güvenilirliğini bilgi kullanıcıları açısından ifade ettiği anlamla değerlendirilebilir. Kanıtın önemliliği bilgiyi kullanacak olan kişi ve kurumların o bilgiden etkilenme oranlarıyla ilişkilidir (Çaldağ, 2007: 70). Genel kabul görmüş muhasebe standartlarına göre denetçi tarafından elde edilecek kanıt sayısı önemlidir. Bu kanıt sayısını belirleyen etkenler; risk, önemlilik, ana kütlenin büyüklüğü olarak tanımlanabilir (Cömert, Uzay, Kardeş, \& Uyar, 2013: 311).

Denetim kanıt miktarı, denetçinin denetlediği işletme bilgilerinin yeterliliği ve güvenilirliğiyle ilgilidir. Aşağıdaki tabloda denetim kanıtının yeterliliği ve güvenilirliğini etkileyen unsurlar sıralanmıştır; 
Tablo 1. Denetim Kanıtının Yeterliliğini ve Güvenilirliğini Etkileyen Unsurlar

\begin{tabular}{|l|l|}
\hline \multicolumn{1}{|c|}{$\begin{array}{c}\text { KANIT MIKTARINI ETKILEYEN } \\
\text { UNSURLAR }\end{array}$} & $\begin{array}{c}\text { KANIT GÜVENIRLIĞiNİ ETKILEYEN } \\
\text { UNSURLAR }\end{array}$ \\
\hline - Önemlilik & - Kanıtın Geçerliliği (Kanıtın İlgili Olması) \\
\hline - Risk & - Kanıtın Kaynağı \\
\hline - Nitelik & - Kanıtın Zamanlılığı \\
\hline - Maliyet (Ekonomik Etmenler) & - Kanıtın Nesnelliği \\
\hline - Ana Kütlenin Büyüklüğg̈ Ve Özelliği & \\
\hline
\end{tabular}

Kaynak: Kütük, 2008.

Denetim çalışmasında denetçi tarafından toplanacak kanıtların ana kütleyi niteleyen kanıtlar olması büyük önem taşımaktadır. Denetim kanıtları, gerçek zamanlı muhasebe kayıtlarının yanında tamamlayıcı nitelikteki bilgilerden oluşan kanıtları da içermektedir. Uluslararası denetim standartlarına göre denetim yapabilmek için elektronik ve manuel muhasebe kayıtlarının yanında tamamlayıcı niteliklerdeki bilgiler de dikkate alınmalıdır. Muhasebe kayıtları ve tamamlayıcı muhasebe kayıtları dikkate alınarak kanıt toplanması gerekmektedir (Kepekçi, 1996: 85).

Muhasebe ortamımda oluşturulan denetim kanttları; muhasebeye konu olan bütün belgeler örneğin; çekler, elektronik fon transferi (EFT) kayıtları, faturalar, yapılmış olan çeşitli sözleşmeler esas ve yardımcı defterler, günlük defterdeki kayıt ve hesaplamalar, mali tablolarda yapılan değişiklikler, maliyet dağıtım tabloları, muhasebe hesapları, dipnotlardaki açılamalar ve bilgiler, mutabakatlar, çalışma kağıtları ve dosyası, çalışma tabloları olarak tanımlanabilir. Muhasebe kanitlarının yanında destekleyici nitelikli kanitlar olarak UDS 500 No'lu standartta aşağıdaki gibi açıklanmıştır:

"Muhasebe kayıtları dışında, denetim kanıtı olarak kullanılabilecek destekleyici kanıtları ise şunlardan oluşmaktadır; toplantı tutanakları (yönetim kurulu, genel kurul vb.), üçüncü taraflarca yapılan teyit ve doğrulamalar, tahlil uzmanları tarafindan hazırlanan tahlil raporları, işletmenin sahiplerine ilişkin karşılaştırmalı veriler, el kitapları (kontrollerle ilgili), rehberler (stok sayım rehberi vb.), denetçi tarafindan yapılan denetim inceleme, soruşturma ve gözlemlerden elde edilen bilgiler, denetçinin denetim kanıtı olarak kullanabileceği

bilgilerdir" (https://www.kgk.gov.tr/Portalv2Uploads/files/Duyurular/v2/BDS/BDS_500_kurumsitesi.pdf).

\subsection{Elektronik Denetim Kanıtları}

2000 y1lında Stevenson G. Smith, "günümüzde üretilen belgelerin yüzde otuzundan daha fazlasinın artık çıktısı alınmamaktadır" (Smith, 2000: 283), diyerek 2000 yıllardan başlamak üzere denetim kanıtlarının elektronik ortama aktarılmasını anlatmıştır. 2021 yılının başlarında artık sadece muhasebe verileri değil hayatımızdaki hemen hemen her şey elektronik kanıtlara dayanmaktadır.

Denetim kanıtlarının elektronik ortamda tutulması; elektronik olarak kaydedilmesi, işlenmesi ve ulaşılmasına elektronik denetim kanıtı denir. Bu kanıtlara örnek olarak elektronik defterlere yapılan bütün muhasebe kayıtları, kaynak oluşturacak belgeler, faturalar, e-sözleşmeler, bilgisayar ortamında olan doğrulamalar özetle sanal ortamda üretilen tüm bilgi ve belgedir (Lavigine, 2002: 42-42). Geleneksel denetim kanitları ve elektronik denetim kanıtları, Tablo 2' de yer aldığı gibi özellikleri bakımından farklılıklar göstermektedir (Şirin, 2006: 31). 
Tablo 2. Geleneksel Denetim Kanıtları ve Elektronik Denetim Kanıtları Arasındaki Farklar

\begin{tabular}{|c|c|}
\hline Geleneksel Denetim Kantlart & Elektronik Denetim Kantlari \\
\hline Değiștirilmesi zordur. & $\begin{array}{l}\text { Değiştirilmesi kolay olup bilgi sistemlerine ilişkin } \\
\text { yapılan değişiklikler özel tasarlanmış testler } \\
\text { gerektirir. }\end{array}$ \\
\hline $\begin{array}{l}\text { Güvenilirliği kaynağın bağımsızlığına ve } \\
\text { yeterliliğine bağlıdır. }\end{array}$ & $\begin{array}{l}\text { Güvenilirliğini elektronik ortama ilişkin } \\
\text { kontrollerin etkinliğinden alır. Hileli, hatalı } \\
\text { olanları doğrudan anlaması zordur. }\end{array}$ \\
\hline $\begin{array}{l}\text { Basılı belge üzerindeki onaylar belgenin } \\
\text { bütünlüğünü tamamlar ve kolayca görülür. }\end{array}$ & $\begin{array}{l}\text { Elektronik onayların elektronik kayda entegre } \\
\text { edilmesi mümkünse de, ek yorum gerektirir. Tüm } \\
\text { onaylar görülmeyebilir. }\end{array}$ \\
\hline $\begin{array}{l}\text { Basılı belgelerin şekli bir iç parçası olup işleme } \\
\text { ilişkin tüm önemli şartları içerir. }\end{array}$ & $\begin{array}{l}\text { İşleme ilişkin önemli unsurlar (bilginin kaynağ1, } \\
\text { gönderilme tarihleri gibi) belgenin bir iç parçası } \\
\text { değildir. Şekil elektronik bilginin bir iç parçası } \\
\text { değildir. }\end{array}$ \\
\hline $\begin{array}{l}\text { Ulaşılabilmesi elde edilmesi ve değerlendirilmesi } \\
\text { kolaydır. }\end{array}$ & $\begin{array}{l}\text { Ulaşılabilmesi elde edilmesi ve değerlendirilmesi } \\
\text { zordur. Bir uzmanın yardımı gerekebilir. }\end{array}$ \\
\hline $\begin{array}{l}\text { Farklı denetçiler güvenilir ve geçerli bir klasik } \\
\text { denetim kanıtından aynı sonuca ulaşırlar. }\end{array}$ & $\begin{array}{l}\text { Denetim kanıtının niteliği her zaman açık değildir. } \\
\text { Uygun kontrollerin yokluğunda benzer elektronik } \\
\text { bilgi formatları yanıltıcı sonuçlara varılmasına } \\
\text { neden olabilir. }\end{array}$ \\
\hline
\end{tabular}

Kaynak: Şirin, 2006: 61.

Elektronik denetim kanıtları geleneksel olarak kâğıt-kalem ile tutulan muhasebe kayıtlarına göre silinebilme, değiştirilme ve kopyalanma riski daha yüksek olan kanıtlardır. Bu nedenle kayıtların yedeklenmesi ve özel güvenlik önlemlerinin alınması gerekmektedir. Elektronik kanıt oluşturan bilginin güvenilir kanıt olabilme özelliği yapılan denetimin amacına, elektronik ortamda üretilen bilginin niteliğine ve kaynağına göre değişmektedir (Lavigine, 2002: 40-42). Elektronik bilginin denetim kanıtı olarak güvenilirliğinin belirlenmesi Tablo 3'de açıklanmıştır.

Tablo 3. Elektronik Bilginin Denetim Kanıtı Olarak Güvenilirliğinin Belirlenmesi

\section{Elektronik Bilginin Denetim Kanut Olarak Güvenilirliğinin Belirlenmesi}

Doğrulama

Bütünlük

Yetki

Reddetmeme

Kaynak: Şirin, 2006.
Bilgiyi üreten kurum ve kişinin kimliğinin tanimlanmasi.

Bilginin gerçekliği, cari niteliği, doğruluğu, tamlığı. Bütünlük geçerliliğinin sağlandığına; yani bilginin hazırlanma, ișlenme, iletilme, alınma süreçlerinde kasten veya tesadüfen değiștirilmediğine ilișkin güvenceyi ifade eder.

Yetkili veya sorumlu kișilerce bilginin hazırlanmasi, işlenmesi, iletilmesi, düzeltilmesi, gönderilmesi, alınması.

Bilginin hazırlanması, iletilmesi, alınması süreçleri içerisinde ilgili tarafların bilgi içeriğini reddetmemesi, ișlemin taraflarca kabulü . 


\section{DENETIM KANITI İLE İLGİLI LITEATÜR İNCELEMESİ}

Denetim kanıtları konusunda yapılan çalışmaları aşağıdaki gibi sıralayabiliriz. 1989 yılında Cindy L. Mockel ve R. David Plumlee; Çalışmalarını 85 denetçi üzerinde uygulamış ve hipotetik (varsayımsal) olarak oluşturulan denetim çalışma kağıtlarını incelenmeleri istenmiş ve aynı işlem bir gün sonra tekrarlanmıştır. Bu tekrarla daha önce inceledikleri çalışma kâğıtlarını tanıma oranlarına bakılmıştır. Bir gün önce inceledikleri çalışma kâğıtlarını tanımaları ve güven derecelendirmesini kullanmaları istenmiştir. Bu çalışmanın sonucu olarak; denetçilere daha önce incelemek üzere verilen kanıtları ilgili raporlarla eşleştirebildiği görülmüştür (Moeckel, 1988: 653-666).

1993 yılında Saurav K. Dutta ve Rajendra P. Srivastava yaptıkları çalışmada, denetçinin denetim kanıtlarının birleştirilmesi ile oluşturacağı bakış açısı üzerinde durmuşlardır. Bilanço hesaplarının oluşturduğu kanıtların değişken bir yapıya sahip oldukları üzerinde durmuşlardır (Dutta, 1993: 137-160).

1995 yılında Hun-Tong Tan; denetçinin yargısında deneyimin rolünü incelemiştir. Denetçinin deneyim ile kanıt tutarlılığının arasında ilgi olduğunu savunmuştur. Yaptığı çalışmada personel değişikliğinin denetime nasıl bir fark getireceğini ölçmek amacıyla iki deney uygulamıştır. Birinci deneyinde Tan; denetimde kanıtlarının tutarlılığı ile sosyal baskılar arasında pozitif bir uyum bulmuştur. İkinci denemede farkındalığı arttırdığını fakat daha önce incelenmiş denetimden kaynaklı olarak tutarlılık etkisini azalttığı belirlenmiştir (Tan H.-T. 1995: 113-135).

2006 yılında Mehmet Şirin "Denetimde Kanıt Teorisi ve Gelişimi” adlı çalışmasında kanıt yaklaşımının manuel kanıt özelliğinin dışında elektronik ortamındaki kanıtların da denetim ortamına etkilediğini vurgulamıştır (Şirin, 2006: 23-37).

2009 yılında Yasuhiro Ohta; "Stratejik Bir Denetimde Denetim Kanıtının Rolü” adlı çalışmasında basit örneklem yöntemi kullanarak elde ettiği kanıtın denetim riskini ortaya koymaya çalışmıştır. Denetim riskini en aza indirgemenin yolunun güvenilir denetim kanıtı bulmaktan geçtiği sonucuna ulaşmıştır (Ohta, 2009: 58-67).

2011 yılında Amanda M. Grosmann ve Robert B. Welker; denetçi yargısında çalışma kağıtlarının objektif olarak düzenlenmesinin etkisini araştırmışlardır. Rassal olarak düzenlenen çalışma kağıtlarının, denetçi yargılarına etkisi incelenmiştir. Araştırmanın sonucunda rassal yapılan düzenlemelerin denetçi yargısını olumsuz etkileyebileceği sonucuna varmışlardır (Grossman \& Robert, 2011: 93-115).

2011 yılında bir başka çalışma da Chen tarafından yapılmış ve çevrimiçi denetimi incelemiştir. Sürekli denetim çeşitlerinden online denetimi incelemiştir. Online denetimde kanıt toplama önerisinde bulunmuştur (Chen, Smieliauskas, \& Trippen, 2011).

2011 yılında Radu Florea ve Ramona Florea; “Denetim Teknikleri ve Denetim Kanıtı" adlı çalışmalarında denetçiler geçerli ve güvenilir kanıt toplamak amacıyla denetim teknikleri kullanarak hesapları kontrol etmeleri gerektiği sonucuna ulaşmışlardır. Ayrıca denetim kanıtı kavramını açıklayarak denetim kanıtlarının etkisi ve kaliteli bir denetimin gerekliliklerini vurgulamışlardır (Florea \& Florea, 2011: 350-358).

2012 yılında David V. Budescu, Mark E. Peacher ve Ira Solomon tarafından yapılan “Denetim Kanıtı, Önemlilik Eşikleri ve Yanlış Beyan Türünün Kapsamı ve Niteliğinin Denetim Riski Üzerindeki Ortak Etkisi" adlı çalışmada hata ve hile sonucu mali tablolarda oluşan yanlış beyan riskini incelemiş ve bu araştırma için simülasyon kullanmıştır. Araştırmanın sonuncuda denetçinin taviz verme düzeyi incelenmiştir (Budescu, Peecher, \& Solomon, 2012: 19-41). 
2012 yılında Ken T. Trotman ve William F. Wright; çalışmalarında denetim kanıtlarını değerlemede hile riskini üçgenleme yöntemiyle incelemişlerdir. Bu inceleme sonunda işletme dışından toplanan kanıtların, işletme tarafından oluşturulan kanıtlardan daha az güvenilir olduğu sonucuna ulaşmışlardır (Trotman \& Wright, 2012: 41-53).

2013 yılında Yifan Zhao ve Noel Harding; İş riski; yöneticilerin savları ile elde edilen beklentiler arasındaki uyum derecesinin değerlendirilmesidir (Zhao \& Harding, 2013:476). İş dünyası ile ilgili denetim kanıtlarını yaptığı keşifsel çalışmada, denetçilerin iş ortamını, bilgi sistemlerini ve finansal tablolarını değerlendirme sıralamalarını, inanç işlevi teorisini dikkate alarak incelemiştir. İş ortamı, bilgi sistemi ve finansal tablolar arasındaki karmaşık ilişkileri yorumlama etkinliğini iyileştirme potansiyeline sahip olup olmadığını araştırmışlardır (Zhao \& Noel, 2013: 476-505).

İlhan Kütük, "Kamu ve Bağımsız Muhasebe Denetiminde Kanıt Toplama Teknikleri” (Kütük, 2008), Adem Deniz, "Bağımsız Denetimde Kullanılan Kanıt Toplama Teknikleri ve Denetçi Açısından Önemi" (Deniz, 2013), Seda Şener Atsız, "Muhasebe Denetiminde Kanıt ve Kanıt Toplama Tekniklerine Analitik Yaklaşım" (Atsız Ş., 2014), Sefa Özdemir Yılmaz, "Uluslararası Denetim Standartlarına Göre Denetim Kanıtları ve Kanıt Toplama Teknikleri" (Yılmaz, 2015) adlı yüksek lisans tezleriyle katkıda bulunmuşlardır.

2013 yılında G. Bradley Bennett ve Richard C. Hatfield çalışmalarında deneyimi az olan denetçilerle, deneyim ve bilgi düzeyi daha yüksek olan denetçilerin müşteri işletmelerle iletişimi anket ve deneysel olarak incelenmiştir. Tecrübesiz denetçiler için müşteri işletme ile yüz yüze görüşerek kanıt toplama zorluğunu incelemiştir. Sonuç olarak; tecrübesiz denetçilerin denetledikleri işletme personeliyle görüşme yolu ile kanıt edinmekten kaçındığını ortaya koymuştur (Bennett \& Hatfield, 2013: 1-35).

2014 yılında Alper Karavardar; matematiksel kanıt kuramı ile incelemiştir. Araştırmanın sonucunda toplanan kanıtlarının matematiksel destek düzeyleri belirlenerek, kanıtta dayalı bir uzman sisteminin desteğini vurgulamıştır (Karavardar, 2014: 1-22).

2017 yılında Neslihan Çetinkaya araştırmasında; denetçiden geçmiş mali tablolar ile ilgili denetim yargısı oluşturmada denetim kanıtının kalitesi üzerinde durmuştur (Çekinkaya, 2017: 109-133).

2018 yılında Ahmet Fethi Durmuş, Fikret Otlu ve Özge Özkan tarafından yapılan çalışmada, denetim kanıtlarının denetim ve denetçi yargısına farklı etki ettiği ve mesleki yeterlilik, ahlaki alg1, etik değerler ve kişiliğinin denetim kanıtlarının incelenmesinde denetçinin görüşünü etkilediğini ortaya koymuştur (Durmuş, Otlu, \& Özkan, 2018: 66-88).

\section{ARAŞTIRMA}

Çalışmanın temelini oluşturan araştırmanın amacı, kapsamı, yöntemi ile anket sonuçlarına bağlı elde edilen verilerin analizine bu bölümünde yer verilmiştir.

\subsection{Araştırmanın Amacı}

$\mathrm{Bu}$ araştırmanın amacı, son sınıfta öğrenim gören ve denetim dersi almış olan öğrencilerden işletme yararına dahi olsa güvenilir kanıta dayanmayan belgeler kullanarak işlem yapmanın doğru olup olmadığı ile ilgili düşüncelerini değerlendirmektir.

Bu amaçla çalışmada; Türkiye' de ilaç sektöründe faaliyet gösteren $(X)$ A.Ş.'e yönelik bir senaryo oluşturulmuştur. Senaryo aşağıdaki şekilde kurgulanmıştır:

(X) A.Ş.'nin içinde bulunulan yılın denetimi sırasında denetçi ve işletme yöneticisi arasında elektronik kayıtlar üzerinde yapılan değişiklikler ile ilgili anlaşmazlık çıkmıştır. İşletme 
denetlenen yılda kar elde etmiş, ancak daha önceki iki yıl üst üste zarar etmiştir. Fakat finans müdürü banka kredisi kullanabilmek için zarar edilen son iki yılı başa baş göstermiştir. Üçüncü yıl karını doğru olarak göstermiştir. Bilançodaki bu düzeltme, işletmenin kredi kullanmasını ve ödemelerinin sıkıntısız bir şekilde yapılmasını sağlamıştır. Ancak denetçi bunu saptamış ve bu durumun yanıltıcı bilgi vermek olduğunu ve bunu denetim raporunda belirtmesi gerektiğini yöneticilere bildirmiştir. Kredi kullanmak amaciyla bankaya verilen elektronik muhasebe belgelerinin ve raporların gerçeği yansıtmadığı görülmüştür. Denetçi, "elektronik kayıtlarda yapılan bu işlenin işletmenin yararına bile olsa muhasebe kanıtlarının güvenirliğini sarstığını" yarg1 etmiştir. Senaryo kapsamında, denetim dersi almış ve gelecekte birer denetçi adayı olacak son sınıf öğrencilerine "işletme yararına dahi güvenilir kanıta dayanmayan belgeler kullanarak işlem yapmanın doğru olup olmadı̆̆ı ile ilgili düşüncelerini değerlendirmek" adına sorular sorulmuştur.

\subsection{Araştırmanın Yöntemi}

İşletmenin muhasebe kayıtları ve mali tablolarında değişiklik yapılmak suretiyle düzeltilmiş bilançonun kullanılması varsayımına dayanan senaryo denetim dersi almış ve gelecekte birer denetçi adayı olacak öğrencilere verilmiştir. Öğrencilerden kendilerini denetçi olarak görmesi istenerek, senaryo hakkındaki görüşleri 5’li likert ölçeğine göre hazırlanmış bir anket aracılı̆̆ı ile sorulmuştur. Araştırmanın ana kütlesi; Düzce, Sakarya ve Bolu illerinde bulunan fakülte ve yüksekokullarda öğrenim gören ve denetim dersi almış olan son sınıf öğrencilerinden oluşturulmuştur. Araştırma evreninin kriterleri belirlenirken, Düzce'ye yakın olan illerde evrende yer alan bireylere ulaşma imkanı kolay ve maliyetinin az olması ve zaman sınırlaması olması gibi faktörler göz önünde bulundurulmuştur. Bir diğer kriter olan son sınıf öğrencilerinin seçilmesinin temel nedeni ise, son sınıf öğrencilerinin hem istediği iş koluna yönelecekleri bir sürecin içinde olmaları hem de gerekli tüm dersleri alarak belli bir bilgi birikimine sahip olmalarıdır. Araştırma evreninin yaklaşık 2500 olması ve hepsine ulaşabilme olanağının olmaması ayrıca yüksek maliyetli olması gibi nedenlerle araştırmaya katılan denetim dersi alan ve bu mesleği yapmaya aday olan 179 son sınıf öğrencisi örneklem olarak belirlenmiştir. 300 öğrenciye anket gönderilmiş ve 179 öğrenciden geri konuş olmuştur. Örnekleme dahil olan 179 öğrenciye "kolayda örnekleme yöntemi" ile ulaşılmıştır. Aşağıdaki formül (Yamane, 2001) ele alınarak örneklem hesaplanmıştır. Yaklaşık 2.500 olan evren için, \% 93 güvenirlik ile gerekli olan örneklem sayısının 157 yeterli iken çalışmada 179 kişiden veri toplanmıştır.

$$
n=\frac{N z^{2} p q}{N d^{2}+z^{2} p q}
$$

Çalışmada verilen senaryoya dayalı olarak birer denetçi adayı olan ve denetim dersi almış son sınıf öğrencilerinin konu hakkındaki düşüncelerini belirlemek amacıyla 5'er soru sorulmuştur. Araştırma kapsamında oluşturulan 5 soru, 5'li likert tipi ölçekle ölçülmüş olup, yargılar en olumsuzdan en olumluya doğru sıralanmıştır.

\subsection{Araştırmanın Bulguları}

Araştırmaya katılan birer denetçi adayı olan ve denetim dersi almış 179 son sınıf öğrencisinden toplanan verilere dayalı olarak yapılan analizler sonucunda elde edilen bulgular aşağıda tablolar halinde sunulmuştur. 

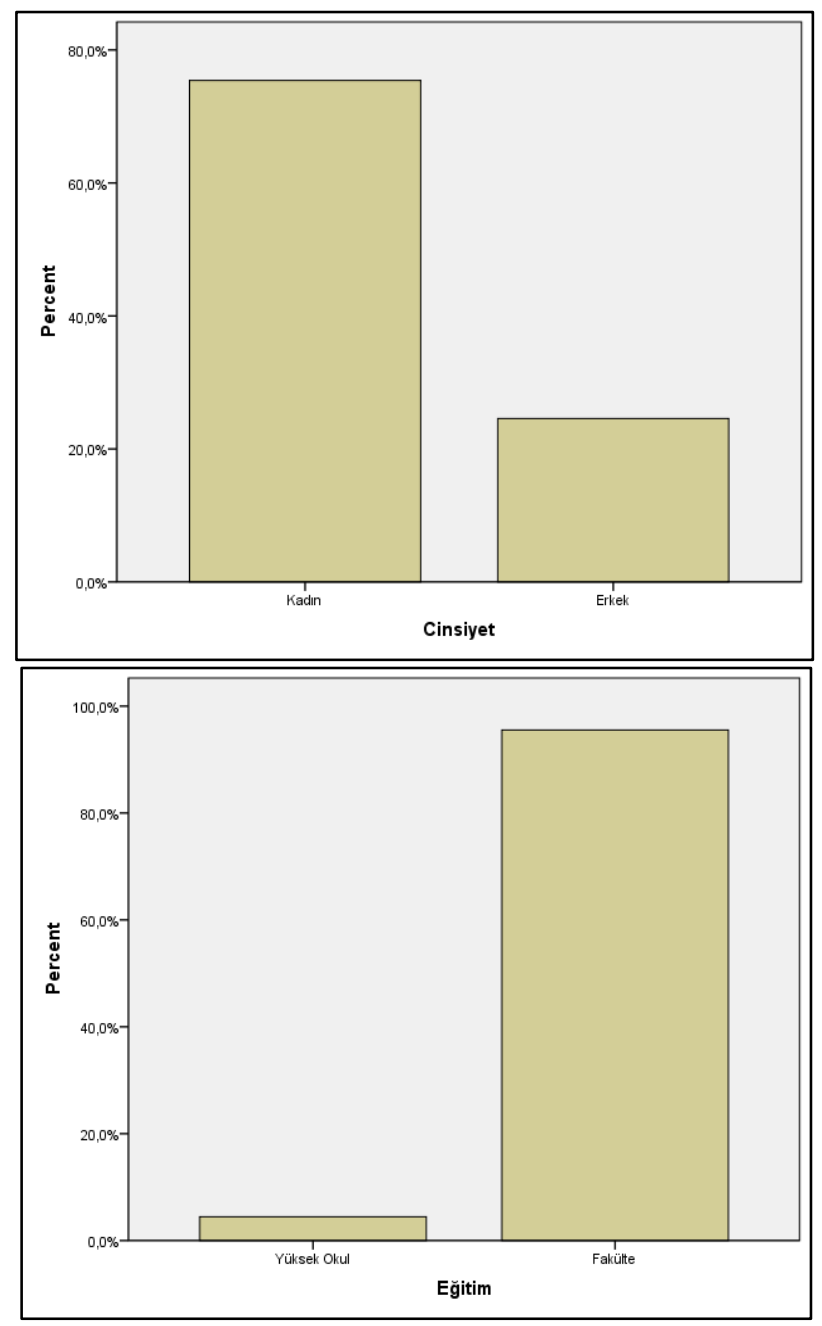

Şekil 1. Denetim Dersi Alan Öğrencilerin Demografik Özelliklerine İlişkin Bulgular

Tablo 4. Denetim Dersi Alan Öğrencilerin Demografik Özelliklerine İlişkin Bulgular

\begin{tabular}{|c|c|c|c|c|c|}
\hline Cinsiyet & $\mathbf{N}$ & $\%$ & Eğitim & $\mathbf{N}$ & $\%$ \\
\hline Kadın & 135 & 75,4 & Yüksekokul & 8 & 4,5 \\
\hline Erkek & 44 & 24,5 & Fakülte & 171 & 95,5 \\
\hline Toplam & 179 & 100 & Toplam & 179 & 100 \\
\hline
\end{tabular}

Araştırma sürecine dâhil olan kadın katılımcıların $(\% 75,4)$, erkek katılımcılara $(\% 24,5)$ göre araştırmaya daha fazla katılım gösterdiği görülmüştür. Eğitim bilgileri dikkate alındığında; \%95,5'lik gibi büyük bir çoğunluğunu fakültede okuyanlar, kalan \% 4,5'lik bölüm ise yüksekokulda okuyan öğrencilerden oluşmaktadır. 


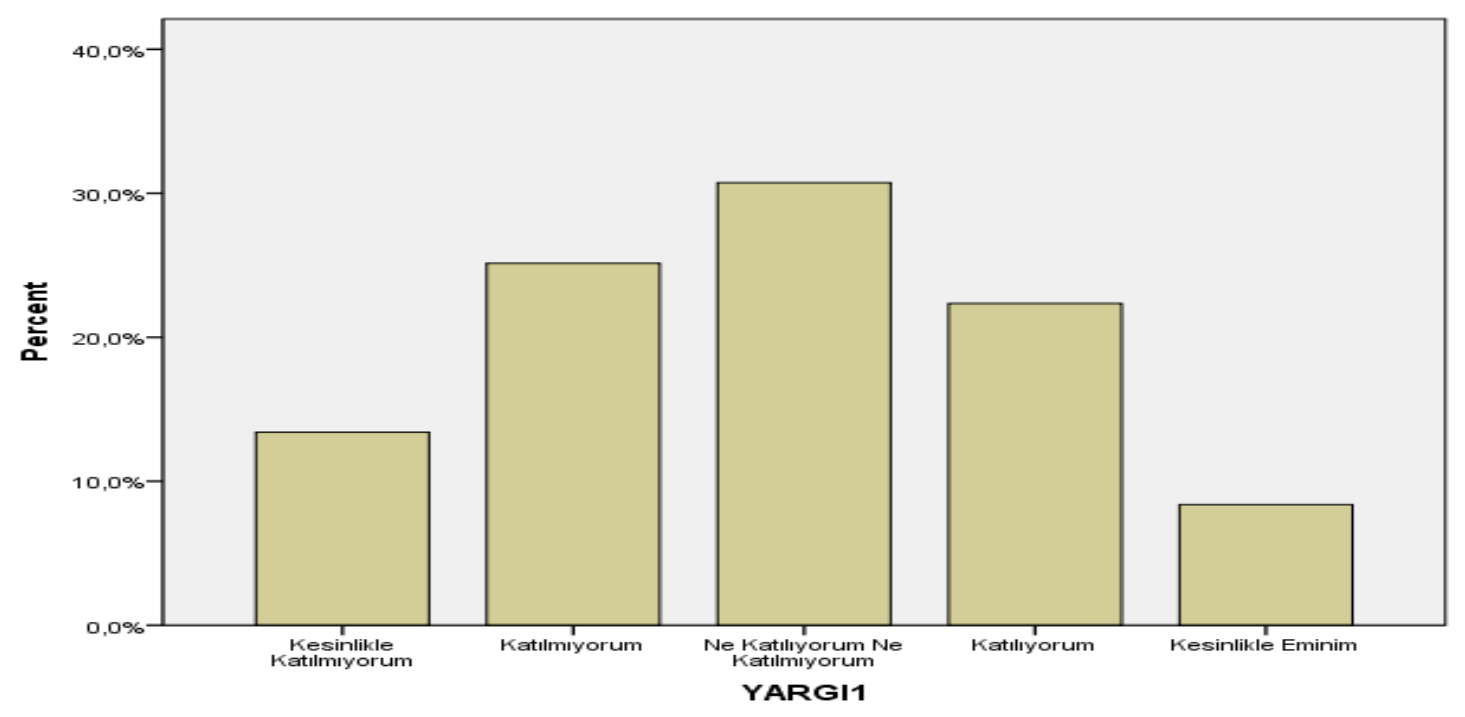

Şekil 2. Denetçi ve Denetim Kanıtı Senaryosuna Yönelik Yargı 1

Tablo 5. Denetçi ve Denetim Kanıtı Senaryosuna Yönelik Yargı 1

\begin{tabular}{|c|c|c|c|c|c|c|}
\hline Yarg1 1 & & 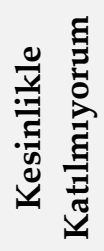 & 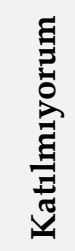 & 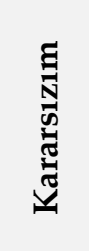 & 吾 & 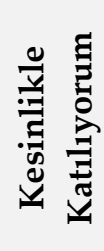 \\
\hline $\begin{array}{l}\text { Birer denetçi adayı olarak; "denetim kanıtları; } \\
\text { yönetimin savları doğrultusunda, gerçekleştiği }\end{array}$ & Frekans & 24 & 45 & 55 & 40 & 15 \\
\hline $\begin{array}{l}\text { öne sürülen olayları gösteren belgeler (yevmiye } \\
\text { kayıtları, faturalar vb.) dikkate alınarak } \\
\text { değerlendirilir." }\end{array}$ & Oran & 13,4 & 25,1 & 30,7 & $\begin{array}{l}22 \\
, 3\end{array}$ & 8,4 \\
\hline
\end{tabular}

Araştırmada verilen senaryoya dayalı olarak, birer denetçi adayı olan öğrencilere denetim kanıtları ile ilgili sorulan sorularla katılım derecelerini belirtmeleri istenmiştir. Bu kapsamda kurgulanan Yarg11: bir denetçi olarak; "denetim kanttları; yönetimin savlar doğrultusunda, gerçekleştiği öne sürülen olayları gösteren belgeler (yevmiye kayıtları, faturalar vb.) dikkate alınarak değerlendirilir" yargısına Tablo 5'da görüldüğü gibi katılımcıların sırayla; \%30,7'si kararsız olduğunu, \%25,1'i emin olmadığını, \%22,3 emin olduğunu, \%13,4'ü hiç emin olmadığını ve $\% 8,4^{\prime}$ ü kesinlikle emin olduklarını belirttikleri görülmüştür. Senaryoda verilen yargı 5:'e katılımcılar \%30,7 kararsızım, \%22,3 katılıyorum, \%8,4 kesinlikle katılıyorum yanitları vererek toplam olarak 61.4 oranında büyük bir çoğunlukla olumlu yanıt vermiştir. 


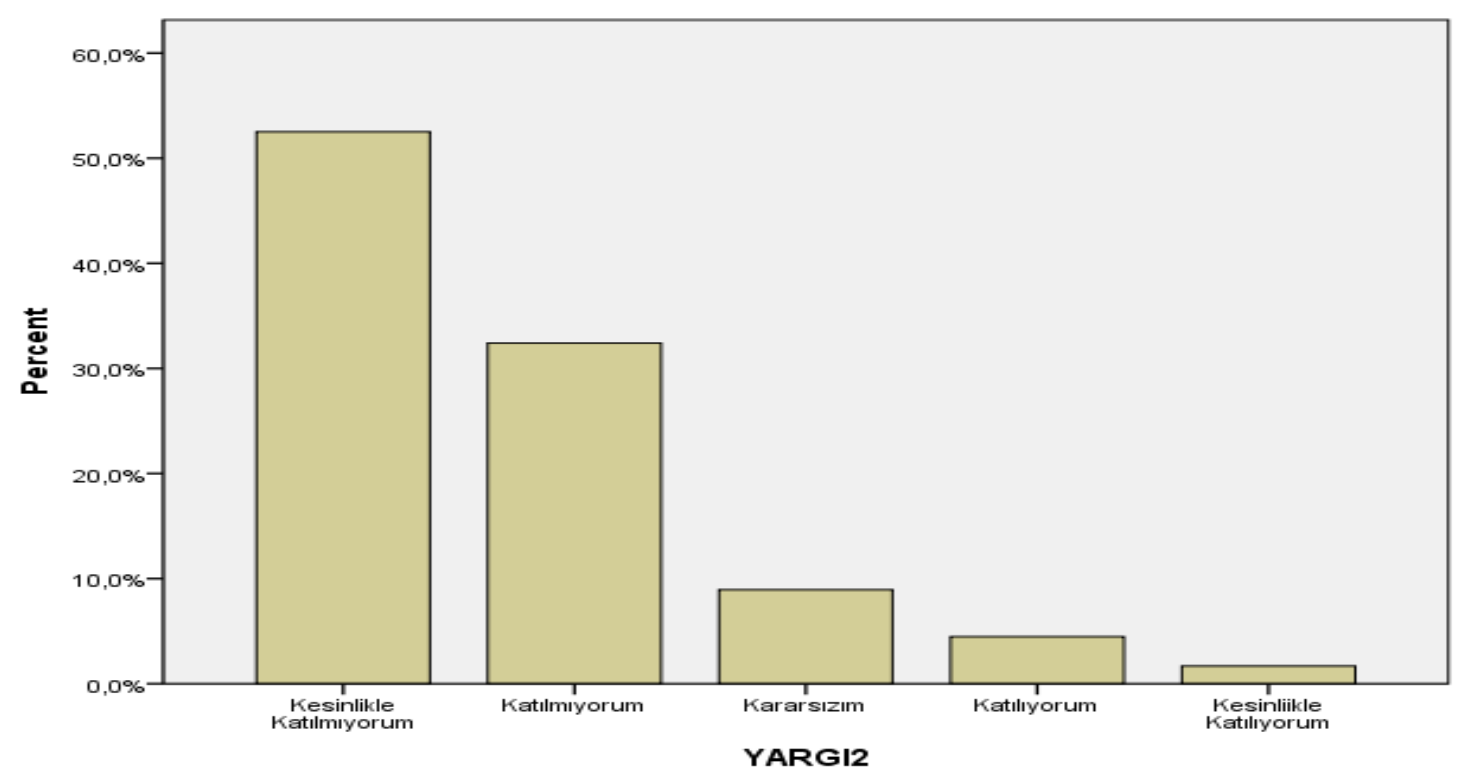

Şekil 3. Denetçi ve Denetim Kanıtı Senaryosuna Yönelik Yarg1 2

Tablo 6. Denetçi ve Denetim Kanıtı Senaryosuna Yönelik Yarg1 2

\begin{tabular}{|c|c|c|c|c|c|c|}
\hline Yarg1 2 & & 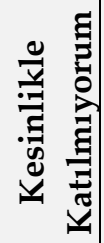 & 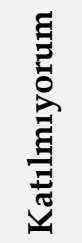 & 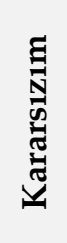 & 全 & 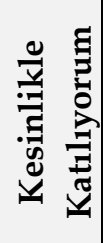 \\
\hline \multirow{2}{*}{$\begin{array}{l}\text { Bir denetçi adayı olarak "işletme yararına } \\
\text { kayıtlardaki düzeltmeleri kabul edebilirim" yargısına } \\
\text { ne kadar katılıyorsunuz. }\end{array}$} & Frekans & 94 & 58 & 16 & 8 & 3 \\
\hline & Oran & 52,5 & 32,4 & 8,9 & 4,5 & 1,7 \\
\hline
\end{tabular}

Araştırmada görüldüğü gibi "işletme yararına kayıtlardaki düzeltmeleri kabul edebilirim" sorusuna birer denetçi adayı olan öğrencilerden katılım derecelerini belirtmeleri istenmiştir. Bu kapsamda kurgulanan Yarg1: 2 "bir denetçi olarak, işletme yararına kayıtlardaki düzeltmeleri kabul edebilirim" yargısına Tablo 6'da da görüldüğü gibi katılımcıların \%52,5'lik bir çoğunluğunun kesinlikle katılmadığını, \%32,4'ünün katılmadığını, \%8,9'unun kararsız kaldığını, \%4,5'inin katıldığını ve $\% 1,7^{\prime}$ lik oranda ise kesinlikle katıldıkları görülmüştür. Bir denetçi olarak kayıt altına alınmayan işlemleri göz ardı edilmemesi gerektiğini düşünen \%84,9'luk büyük bir çoğunluk olduğu tespit edilmiştir. 


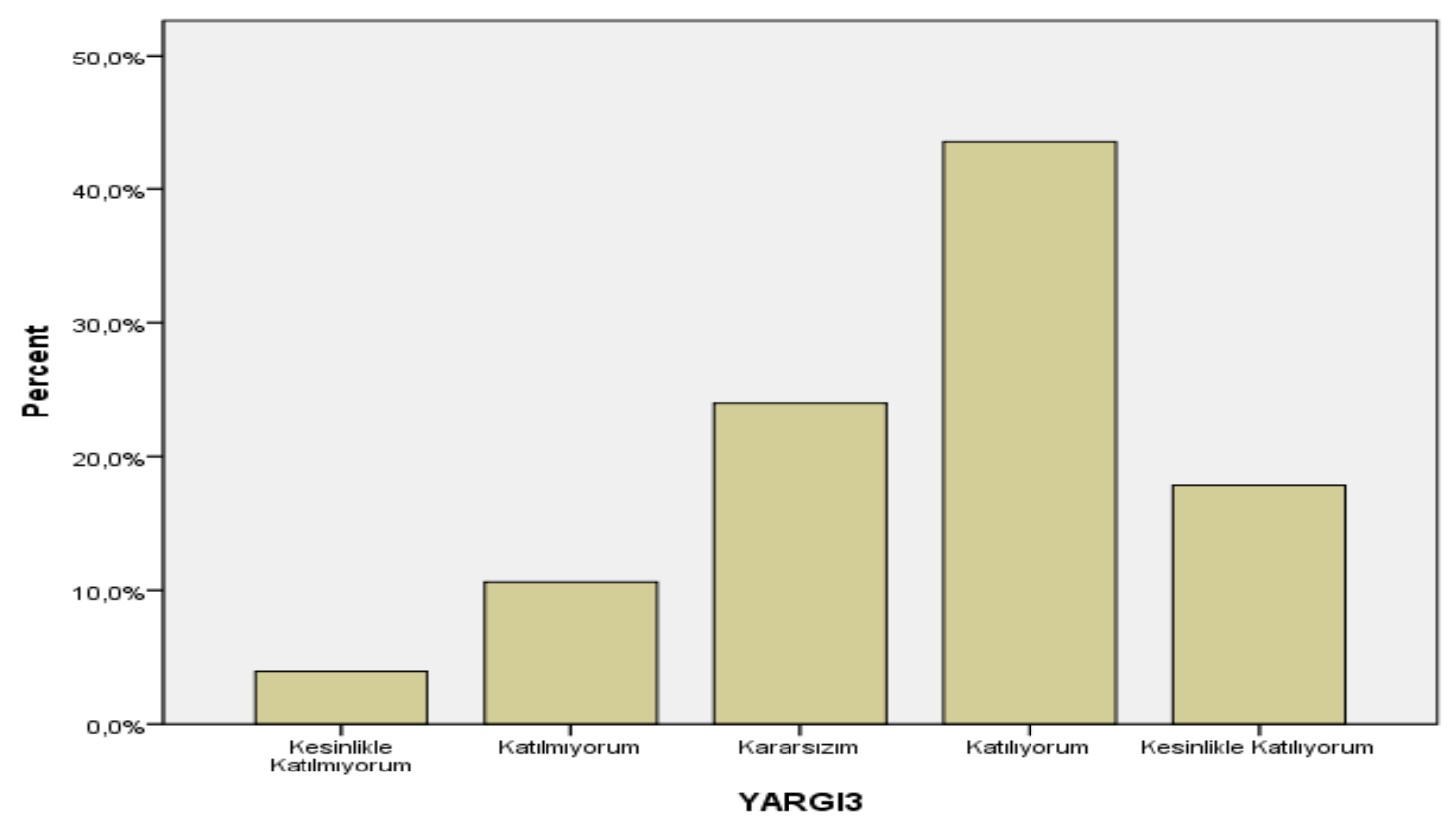

Şekil 4. Denetçi ve Denetim Kanıtı Senaryosuna Yönelik Yargı 3

Tablo 7. Denetçi ve Denetim Kanıtı Senaryosuna Yönelik Yarg1 3

\begin{tabular}{|c|c|c|c|c|c|c|}
\hline Yarg1 3 & & 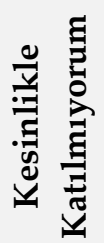 & 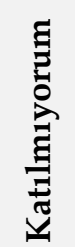 & 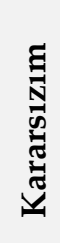 & 章 & 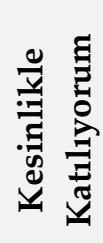 \\
\hline \multirow{2}{*}{$\begin{array}{l}\text { "Denetim kanıtl, denetçinin nesnel yargı } \\
\text { oluşturmak için kullandığı kayıtlı ve kayıtsız } \\
\text { bütün bilgilerdir" yargisına ne kadar } \\
\text { katıliyorsunuz. }\end{array}$} & Frekans & 7 & 19 & 43 & 78 & 32 \\
\hline & Oran & 3,9 & 10,6 & 24 & $\begin{array}{c}43 \\
6\end{array}$ & 17,9 \\
\hline
\end{tabular}

Araştırmada verilen senaryoya dayalı olarak, birer denetçi adayı olan öğrencilere denetim kanitları ile ilgili sorulan soruya katılım derecelerini belirtmeleri istenmiştir. Bu kapsamda kurgulanan Yarg1 3: "denetim kanıtı, denetçinin nesnel yargı oluşturmak için kullandığı kayıtlı ve kayıtsız bütün bilgilerdir" yargısına Tablo 7'de görüldüğü gibi katılımcıların sırasıyla \%43,6'sının katıldığını, \%24'ünün kararsız kaldığını, \%17,9'unun kesinlikle katıldığını, \%10,6'sının katılmadığını ve geriye kalan \%3,9'unun kesinlikle katılmadığını belirtmişlerdir. Araştırmada bir denetçinin nesnel yargısını oluşturmak için kullandığı kayıtlı ve kayıtsız bütün bilgilerin denetim kanitı olduğunu düşünen \% 61, 5’lik büyük bir çoğunluk olduğu tespit edilmiştir. 


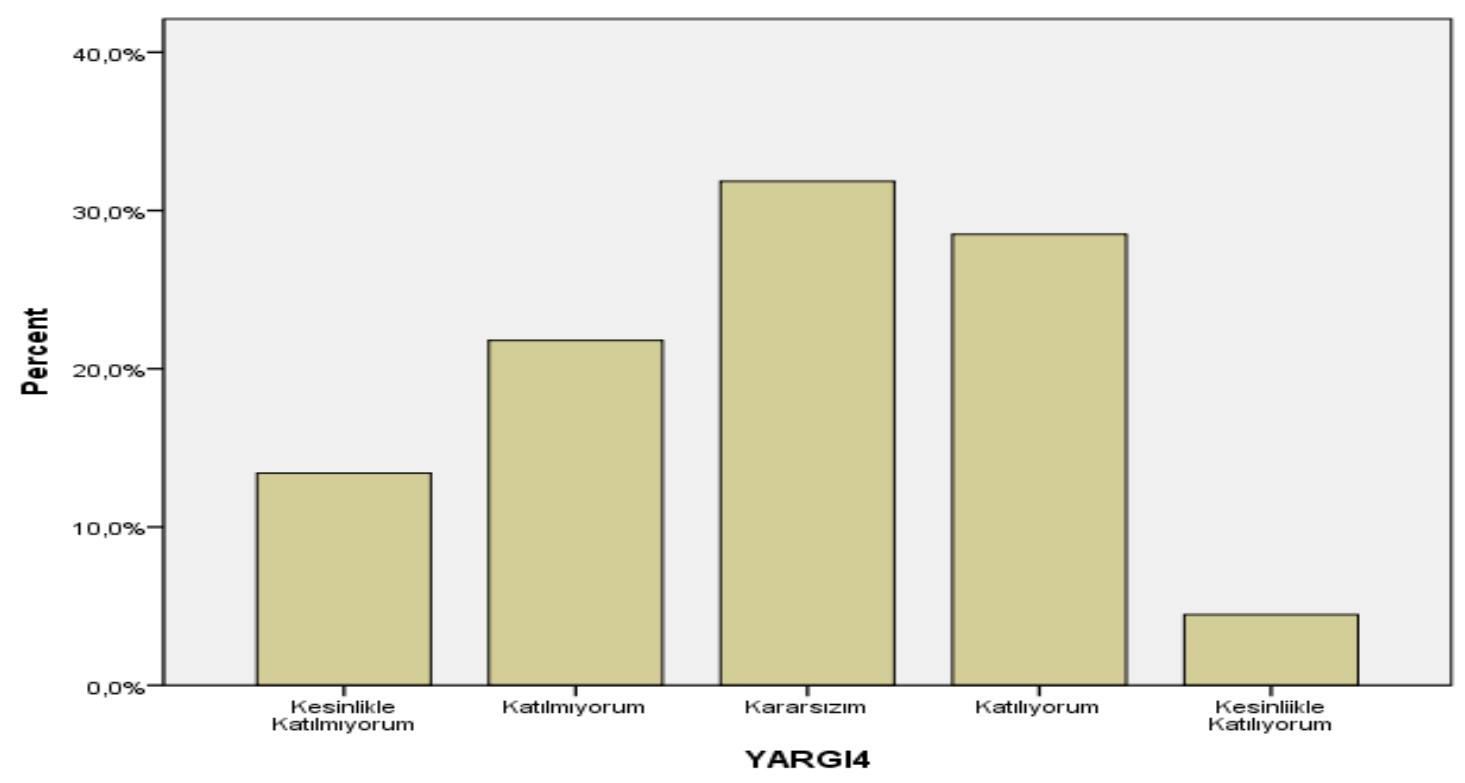

Şekil 5. Denetçi ve Denetim Kanıtı Senaryosuna Yönelik Yargı 4

Tablo 8. Denetçi ve Denetim Kanıtı Senaryosuna Yönelik Yarg1 4

\begin{tabular}{|c|c|c|c|c|c|c|}
\hline Yarg1 4 & & 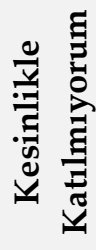 & 吾 & 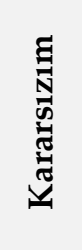 & 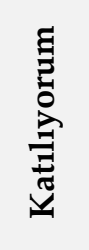 & 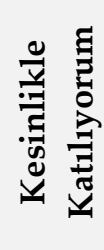 \\
\hline $\begin{array}{l}\text { Bir denetçi adayı olarak "elektronik denetim } \\
\text { kanıtlarını basılı belgelere oranla daha az güvenilir }\end{array}$ & Frekans & 24 & 39 & 57 & 51 & 8 \\
\hline $\begin{array}{l}\text { buluyorum" yargisına } \\
\text { belirtiniz. }\end{array}$ & Oran & 13,4 & 21,8 & 31,8 & 28,5 & 4,5 \\
\hline
\end{tabular}

Araştırmada verilen senaryoya dayalı olarak, birer denetçi adayı olan öğrencilere denetim kanıtları ile ilgili soruya katılım derecelerini belirtmeleri istenmiştir. Bu kapsamda kurgulanan Yarg1 4: "bir denetçi olarak "elektronik denetim kanıtlarım basılı belgelere oranla daha az güvenilir buluyorum" yargısına Tablo 8'de görüldüğü gibi katılımcıların sırasıyla \%31,8'nin kararsız kaldığını, \%28,5'inin katıldığını, \%21,8'inin katılmadığını, \%13,4'ünün kesinlikle katılmadığını ve geriye kalan \%4,5'inin ise kesinlikle katıldıkları görülmüştür. Katılımcların (\%31,8 karasızlar, 28,5 katılanlar ve 4,5 kesinlikle katılanların) \%64,8'lik büyük bir oranında "elektronik denetim kanıtlarını basılı belgelere oranla daha az güvenilir buluyorum" yargısına katıldıkları görülmüştür. 


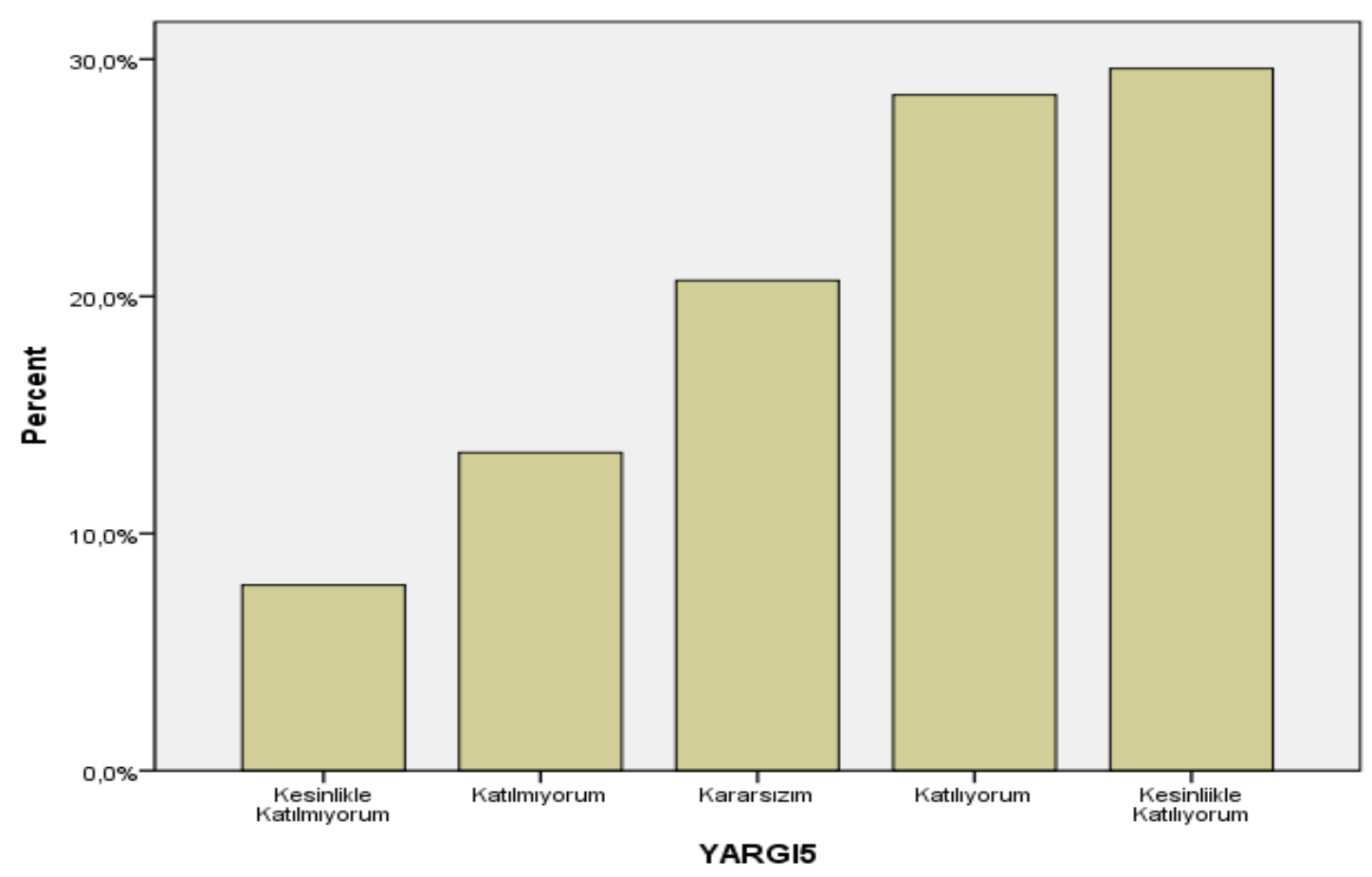

Şekil 6. Denetçi ve Denetim Kanıtı Senaryosuna Yönelik Yarg1 5

Tablo 9. Denetçi ve Denetim Kanıtı Senaryosuna Yönelik Yarg1 5

\begin{tabular}{|c|c|c|c|c|c|c|}
\hline Yarg1 5 & & 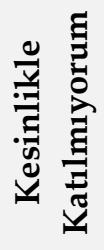 & 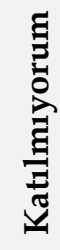 & 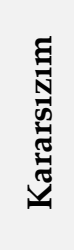 & 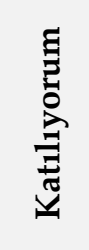 & 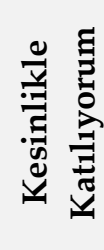 \\
\hline \multirow{2}{*}{$\begin{array}{l}\text { Denetçinin görevi hata ve hileleri önlemek } \\
\text { değil, makul güven oluşturacak kanitları } \\
\text { toplamaktır. }\end{array}$} & Frekans & 14 & 24 & 37 & 51 & 53 \\
\hline & Oran & 7,8 & $\begin{array}{l}13 \\
4\end{array}$ & 20,7 & 28,5 & 29,6 \\
\hline
\end{tabular}

Araştırmada verilen senaryoya dayalı olarak birer denetçi adayı olan öğrencilere denetçilerin özelliklerini içeren soruya katılım derecelerini belirtmeleri istenmiştir. Bu kapsamda kurgulanan Yarg1 5: "Denetçinin görevi hata ve hileleri önlemek değil, makul güven oluşturacak kamitları toplamaktır" yargısına Tablo 9'da görüldüğü gibi katılımcıların sırasıyla \%29,6'sının kesinlikle katıldığını, \%28,5'inin katıldığını, \%20,7'sinin kararsız kaldığını, \%13,4' ünün katılmadığını ve geriye kalan $\% 7,8$ 'nin ise kesinlikle katılmadıkları görülmüştür. Katılımcıların $\% 58,1^{\prime}$ lik büyük bir oranı ise "Denetçinin görevi hata ve hileleri önlemek değil, makul güven oluşturacak kanıtlarn toplamaktır" yargısına katıldıklarını belirtmişlerdir. 


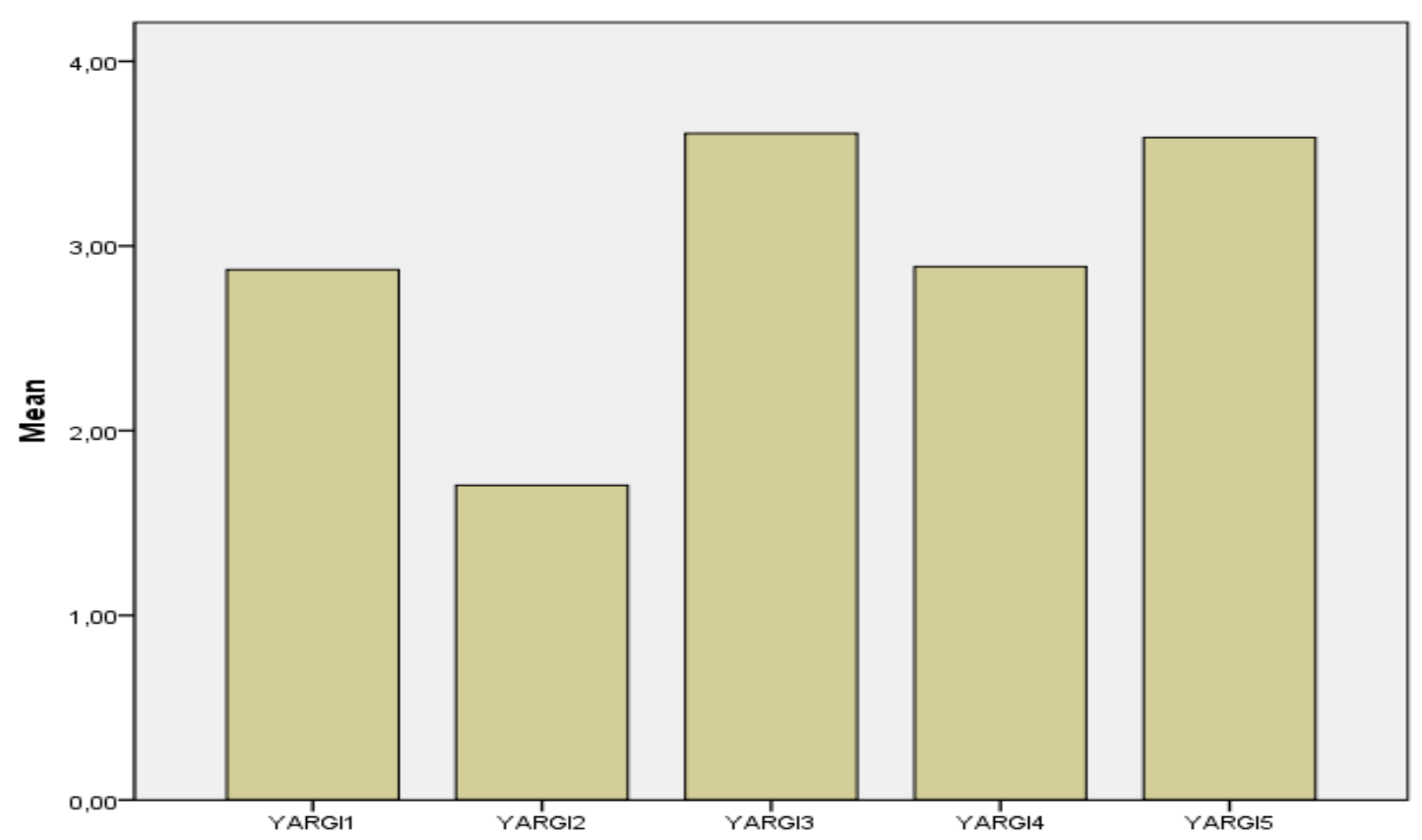

Şekil 7. Denetim ve Denetçi Kanıtlarıyla İlgili Genel Görüşler

Tablo 10. Denetim ve Denetçi Kanıtlarıyla İlgili Genel Görüşler

\begin{tabular}{|c|c|c|c|c|}
\hline & Yargilar & $\begin{array}{c}\text { Ortalama } \\
\text { Değer }\end{array}$ & $\begin{array}{c}\text { Standart } \\
\text { Sapma }\end{array}$ & $\begin{array}{l}\text { Katılım } \\
\text { Düzeyi }\end{array}$ \\
\hline 1 & $\begin{array}{l}\text { Birer denetçi adayı olarak; "denetim } \\
\text { kanıtları; yönetimin savları } \\
\text { doğrultusunda, gerçekleştiği öne } \\
\text { sürülen olayları gösteren belgeler } \\
\begin{array}{l}\text { (yevmiye kayıtları faturalar vb.) } \\
\text { dikkate alınarak değerlendirilir." }\end{array}\end{array}$ & 2,8715 & 1,15643 & Orta \\
\hline 2 & $\begin{array}{l}\text { Bir denetçi adayı olarak "işletme yararına } \\
\text { kayıtlardaki düzeltmeleri kabul edebilirim" } \\
\text { yargısına ne kadar katılıyorsunuz. }\end{array}$ & 1,7039 & 92805 & Çok Düşük \\
\hline 3 & $\begin{array}{l}\text { "Denetim kanıtı, denetçinin nesnel yargı } \\
\text { oluşturmak için kullandığ kayıtlı ve } \\
\text { kayıtsız bütün bilgilerdir" yargısına ne } \\
\text { kadar katılıyorsunuz. }\end{array}$ & 3,6089 & 1,02394 & Yüksek \\
\hline 4 & $\begin{array}{l}\text { Bir denetçi adayı olarak "elektronik } \\
\text { denetim kanıtlarını basılı belgelere } \\
\text { oranla daha az güvenilir buluyorum" } \\
\text { yargısına katılma derecenizi belirtiniz. }\end{array}$ & 2,8883 & 1,10098 & Orta \\
\hline 5 & $\begin{array}{l}\text { Denetçinin görevi hata ve hileleri } \\
\text { önlemek değil, makul güven } \\
\text { oluşturacak kanitları toplamaktır. }\end{array}$ & 3,5866 & 1,25736 & Yüksek \\
\hline
\end{tabular}


Araştırmaya katılan birer denetçi adayı olan ve denetim dersi almış 179 son sınıf öğrencisine yöneltilen araştırmayı oluşturan yargıların ortalama ve standart sapma değerlerine bu bölümde yer verilmiştir. Yapılan analiz sonucunda her bir yargının ortalama değeri 1,00-1,80 aralığındaysa çok düşük, 1,81-2,60 aralığındaysa düşük, 2,61-3,40 aralığındaysa orta, 3,41-4,20 aralığındaysa yüksek ve 4,21-5,00 aralığındaysa çok yüksek düzeyli katılımı temsil etmektedir (Ajiwibawani vd., 2017; Koçyiğit ve Elitaş, 2018).

Belirlenen ortalama değer aralıklarından hareketle Tablo 10'daki yargılar değerlendirildiğinde "Denetim kanıtı, denetçinin nesnel yargı oluşturmak için kullandığı kayıtlı ve kayıtsız bütün bilgilerdir $(3,6089)$ " ve "Denetçinin görevi hata ve hileleri önlemek değil, makul güven oluşturacak kanıtları toplamaktır $(3,5866)$ " yargılarına yüksek düzeyde katılım olurken sırasıyla "Bir denetçi adayı olarak elektronik denetim kanıtlarını basılı belgelere oranla daha az güvenilir buluyorum $(2,8883)$ ve "Birer denetçi adayı olarak; denetim kantları; yönetimin savları doğrultusunda, gerçekleştiği öne sürülen olayları gösteren belgeler (yevmiye kayıtları, faturalar vb...) dikkate alınarak değerlendirilir (2,8715)" yargılarına orta düzeyli bir katılım olduğu belirlenmiştir. En düşük düzeyli katılımı ise "Bir denetçi adayı olarak "işletme yararına kayıtlardaki düzeltmeleri kabul edebilirim" yargısına $(1,7039)$ " olduğu belirlenmiştir.

\section{SONUÇ}

Denetimde bilgi kullanıcılarına sunulacak bilginin ve denetimin kalitesi açısından kanıt olarak kullanılan belge ve bilgilerin güvenilirliği büyük önem arz etmektedir. Toplanacak kanitın güvenilirliği ile kanıt miktarı arasında ters yönlü bir ilişki söz konusudur. Denetlenecek olan veriye güven ne kadar fazlaysa, toplanacak kanit miktarı o derece az olacaktır. Ayrıca toplanacak kanıt miktarı, ana kütleyi temsil edebilecek büyüklükte olmalıdır. Denetim kanıtının güvenilirliğini ise; kanıtın geçerliliğine, kanıtın zamanlılığına, kanıtın kaynağına ve kanıtın objektifliğine bağlıdır.

Denetim kanıtları üzerine yapılan çalışmaya kadın katılımcıların (\%75,4), erkek katılımcılara $(\% 24,5)$ oranında katılım sağladıkları görülmüştür. Fakültede okuyanlar $(\% 95,5)$ yüksekokulda $(\% 4,5)$ okuyanlara göre daha fazla katılım sağlamışlardır. Verilen senaryoda kurgulanan Yargı 1: Bir denetçi olarak; "denetim kanıtlarl; yönetimin savlar doğrultusunda, gerçekleştĭ̆i öne sürülen olayları gösteren belgeler dikkate alınarak değerlendirilir" yargısına bir denetçi olarak katılımcılar $\% 38,5$ oranında olumsuz yanit verirken, \%61,4 oranında (kararsızım, katıliyorum kesinlikle katılıyorum) büyük bir çoğunlukla olumlu yanıt vermişlerdir. Bu sonuç ile denetçi adayları, denetim kanıtlarını yönetimin öne sürdüğü savların doğruluğunu test etmek amacıyla toplaması gerektiğinin önemine katıldıklarını vurgulamaktadır. Yargı 2: "Bir denetçi olarak, işletme yararına kayıtlardaki düzeltmeleri kabul edebilirim" yargısına katılımcıların \%84,9 (\%52,5'lik kesinlikle katılmıyorum, \%32,4'ünün katılmıyorum) oranında kesinlikle katıldıkları görülmüştür. Bir denetçi olarak kayıt altına alınmayan kanıtı olmayan işlemlerin işletme yararına bile olsa kabul edilemeyeceği sonucu çıkmıştır. İşletmenin yarana bile olsa bilgi kullanıcılarına doğru bilgi vermek gerekmektedir. Saklanılan bilgi kullanıcısını zarara uğratmayacak bile olsa etik bir davranış değildir ve denetçi hiçbir koşulda bu duruma göz yummamalıdır. Yargı 3: "Denetçi adayı öğrencilerden "denetim kanıtı, denetçinin nesnel yargı oluşturmak için kullandığı kayıtlı ve kayıtsız bütün bilgilerdir" yargısını değerlendirmeleri istenmiştir. Katılımcılar \% 61.5 gibi bir 
oranla verilen yargıya katıldıkların belirtmişlerdir. Bu sonuç denetim kanıtlarının denetçinin nesnel yarg1 oluşturmak için önemini bir kez daha vurgulamıştır. Yarg1 4: "Bir denetçi olarak "elektronik denetim kantlarım basıl belgelere oranla daha az güvenilir buluyorum" yargısına katılımcıların \%64,8'lik büyük bir oranda katıldıkları görülmüştür. Elektronik kanıtların değiştirilme kolaylığının basılı kanıtlara göre daha fazla olması denetçi açısından risk taşımaktadır. Yargı 5:"Denetçinin görevi hata ve hileleri önlemek değil, makul güvence oluşturacak kanıtları toplamaktır" yargısına katılımcıların \%58,1'lik büyük bir oranda katıldıklarını belirtmişlerdir. Denetçinin görevi hata ve hileleri önlemek değil, hata ve hileleri ortaya çıkarmaktır. Denetçinin amacı makul güven oluşturmaktır. Makul güvence ise finansal tabloların nitelik ve nicelik bakımından önemli bir yanlışlık içermediğine dair güven oluşturmak amacıyla yeterli miktarda, uygun ve bağımsız denetim kanıtının toplanmasıdır.

Denetim raporunun güvenirliği denetim kanıtının kalitesi ve oluşturduğu makul güvence ile belirlenir. Denetçinin denetim kanıtına elektronik ortamda ulaşmasının söz konusu olması teknoloji bilgisine sahip denetçilerin önemini ortaya çıkarmıştır.

\section{KAYNAKÇA}

Ajiwibawani, M.P., Harti; Subroto W.T. (2017), The Effect of Achievement Motivation, Adversty Quotient And Entrepreneurship Experience on Students Entrepreneurship Attitude, International Journal Of Academic Research in Business and Social Sciences, 7 (9): 445.

Atsız Ş., S. (2014), Muhasebe Denetiminde Kanıt ve Kanıt Toplama Tekniklerine Analitik Yaklaşım. İstanbul: Okan Üniversitesi,Sosyal Bilimler Enstitüsü, Yüksek Lisans Tezi, İstanbul.

Bennett, G. B., \& Hatfield, R. C. (2013), The Effect of the Social Mismatch between Staff Auditors and Client Management on the Collection of Audit Evidence, The Accounting Review, 88 (1): $1-35$.

Budescu, D. V., Peecher, M. E., \& Solomon, I. (2012), The joint influence of the extent and nature of audit evidence, materiality thresholds, and misstatement type on achieved audit risk, A Journal of Practice \& Theory, 31 (2): 19-41.

Cömert, N., Uzay, Ş., Kardeş, S. S., \& Uyar, S. (2013), Uluslararas ıDenetim Standartları Kapsamında Bağımsız Denetim, Sakaraya: Sakarya Üniversitesi Sürekli Eğitim ve Araştırma.

Chen, W., Smieliauskas, W. J., \& Trippen, G. (2011), An audit evidence gathering model in online auditing environments. IEEE International Conference on Systems, Man, and Cybernetics Anchorage, AK, ABD.

Çaldağ, Y. (2007), Denetim ve Raporlama, Ankara: Gazi Kitabevi.

Çekinkaya, N. (2017), "Risk Odaklı Denetimde Denetim Kanıtının Kalitesinin önemi ve Bir Araştırma", Muhasebe Bilim Dünyası, 19 (1): 109-133.

Çil, S. (2013), "Denetimde Kanıt Seçmede Örnekleme ve Diğer Yöntemlerin Kullanımı ve ISO No. 530", GÜTTEF Dergisi.

Deniz, A. (2013), Bă̆ımsız Denetimde Kullanılan Kanıt Toplama Teknikleri ve Denetçi Açısından Önemi. İstanbul: Okan Üniversitesi, Sosyal Bilimler Ensitütüsü, Yüksek Lisans Tezi. 
Durmuş, A. F., Otlu, F., \& Özkan, Ö. (2018)," Denetim Kanıtı Kalitesinin Denetçi Görüşüne Etkisi: Literatür İncelemesi", Akademik Yaklaşım, 9 (1): 66-88.

Dutta, S. K.; Srivastava, R., P.;(1993), "Aggregation of Evidence in Auditing: A Likelihood Perspective", A Journal of Practice \& Theory, 12: 137-160 .

Erdoğan, M. (2006), Denetim, Ankara: Maliye ve Hukuk Yayınları.

Florea, R.; Florea, (2011), "Audit Techniques and Audit Evidence, Economy Transdisciplinarity Congnition", 14 (12): 350-358.

Grossman, A. M., \& Robert, B. (2011), "Does the Arrangement of Audit Evidence According to Causal Connections Make Auditors More Susceptible to Memory Conjunction Errors?", Behavioral Research in Accounting, 23 (2): 93-115.

Hatherly, J. D. (1980), The Audit Evidence Process, İngiltere/ Londra: Anderson Keenan Publishing Limited.

Karavardar, A. (2014), "Denetimde Matetatiksel Kanıt Kuramı Kullanımı: Bir Üretim işletmesindeki Alıcı ve Satıcılar Hesap Denetimleri İçin Bir Uygulama", Uludağ Üniversitesi İktisadi ve İdari Bilimler Fakültesi Dergisi, 33 (2): 1 - 22.

Kepekçi, C. (1996), Bağımsız Denetim, Ankara: Lazer Ofset Matbaa.

Koçyiğit, Ç. S ; Elitaş ,E.L.; (2018) Serbest Muhasebeci Mali Müşavirlerin (SMMM) Etik Alg1 İle İşe Bağlılıkları Arasındaki İlişkiyi Belirlemeye Yönelik Bir Araştırma: Yalova İli Örneği, Modavica 2018, Vol.2, s.82

Kütük, İ. (2008), Kamu ve Bağımsız Muhasebe Denetiminde Kanıt Toplama Teknikleri. Edirne: Trakya Üniversitesi, Sosyal Bilimler Enstitüsü, Yüksek Lisans Tezi.

Lavigine, A. E. (2002, Eylül), Going Electronic, CA Magazine: 40-42.

Moeckel, C. L. (1988), "Auditors' Confidence in Recognition of Audit Evidence", The Accounting Review, 64 (4): 653-666.

Ohta, Y. (2009), "The Role of Audit Evidence in A Strategic Audit", Journal of Accounting and Public Policy, 28 (1): 58-67.

Ratcliffe, T. A. (2002), "Information Technology Internal Control, and Financial Statement Audits", The CPA Journal, 72 (4).

Şirin, M. (2006, Haziran), "Denetimde Kanıt Teorisi ve Gelişimi", Sayıştay Dergisi, 61: 23-37.

Tan, H.-T. (1995), "Effects of Expectations, Prior Involvement, and Review Awareness on Memory for Audit Evidence and Judgment", Journal of Accounting Research, 33 (1): 113-135.

Trotman, K. T.; Wright, W. F. (2012), "Triangulation of Audit Evidence in Fraud Risk Assessment", Accounting Organizations and Society, 37 (1): 41-53.

Yamane, T. ( 2001), Temel Örnekleme Yöntemleri, Çev: Alptekin Esin, M. Akif Bakır, Celal Aydın, Esen Gürbüzsel, Literatür Yayınları, İstanbul

Yılmaz, S. Ö. (2015), Uluslararası Denetim Standartlarına Göre Denetim Kanıtları ve Kanıt Toplama Teknikleri, İstanbul: İstanbul Ticaret Üniversitesi, Sosyal Bilimler Enstitüsü, Muhasebe ve Denetim Anabilim Dalı, Yüksek Lisans Tezi.

Yoon, K. L. (2015), Big Data as Complementary Audit Evidence, American Accounting Association, 29 (2): 431-438. 
Zhao, Y.; Harding, N. (2013), Improving the Interpretation of Complex Audit Evidence: The Beneficial Role of Order Effects, Abacus, 49 (4): 476-505.

www.aicpa.org., (Erişim Tarihi: 14.11.2020).

https://www.ifac.org/., (Erişim Tarihi: 21.10.2020).

https://www.kgk.gov.tr/Portalv2Uploads/files/Duyurular/v2/BDS/BDS_500_kurumsitesi.pdf, (ErişimTarihi: 10. 10. 202).

https://www.sayistay.gov.tr/tr/Upload/95906369/files/mevzuat/Standartlar/ISSAI_1500.pdf,

(Erişim Tarihi: 01.01. 2021). 